\title{
PENGARUH LITERASI EKONOMI DAN PENGALAMAN PRAKERIN TERHADAP MINAT BERWIRAUSAHA PESERTA DIDIK KELAS XI KOMPETENSI KEAHLIAN ADMINISTRASI PERKANTORAN (APK) SMK NEGERI 1 POGALAN TAHUN PELAJARAN 2017/2018
}

\author{
Yahya Reka Wirawan ${ }^{1)}$, Flora Puspitaningsih ${ }^{2)}$ \\ Universitas PGRI Madiun ${ }^{1)}$, Program Studi Pendidikan Ekonomi STKIP PGRI Trenggalek ${ }^{2)}$ \\ yahyareka@unipma.ac.id ${ }^{1)}$, florapuspita70@gmail.com ${ }^{2}$
}

\begin{abstract}
This study aims to determine whether there is influence either partially or simultaneously between economic literacy and prakerin experience of entrepreneurship interest of class XI students of Office Administration (APK) program of SMK Negeri 1 Pogalan year lesson 2017/2018. This research is a quantitative research. Population in this research is class XI student of Office Administration skill program (APK) amounting to 73 students. Sampling technique by nonprobability sampling. Samples in this study were 73 students. Data analysis techniques using SPSS Version 23.00 For Windows. The result of data analysis in this research shows that can be concluded that there is a significant influence between economic literacy and prakerin experience of entrepreneurship interests kelsi XI skill program Administrative Office (APK) SMK Negeri 1 Pogalan year lesson 2017/2018. Overall influence of economic literacy and prakerin experience to entrepreneurship interest equal to $21,6 \%$, while the rest equal to $78,4 \%$ influenced by other factors outside of variable in this research. The results of this study can be used as input and consideration material for learners, teachers and institutions to improve the quality of education and inculcate entrepreneurship interests in learners and can serve as a reference for further research by developing existing research.
\end{abstract}

Keywords : Economic Literacy, Prakerin Experience, Interest in Entrepreneurship.

\begin{abstract}
Abstrak
Penelitian ini bertujuan untuk mengetahui ada tidaknya pengaruh baik secara parsial maupun secara simultan antara literasi ekonomi dan pengalaman prakerin terhadap minat berwirausaha peserta didik kelas XI Kompetensi Keahlian Administrasi Perkantoran (APK) SMK Negeri 1 Pogalan tahun pelajaran 2017/2018. Populasi dalam penelitian ini adalah peserta didik kelas XI Kompetensi Keahlian Administrasi Perkantoran (APK) yang berjumlah 73 peserta didik. Teknik pengambilan sampel dengan cara nonprobability sampling. Sampel dalam penelitian ini adalah 73 peserta didik. Teknik analisis data menggunakan bantuan program SPSS Versi 23.00 For Windows. Hasil analisis data dalam penelitian ini menunjukkan bahwa terdapat pengaruh yang signifikan antara literasi ekomomi dan pengalaman prakerin terhadap minat berwirausaha peserta didik kels XI Kompetensi Keahlian Administrasi Perkantoran (APK) SMK Negeri 1 Pogalan tahun pelajaran 2017/2018. Secara keseluruhan pengaruh literasi ekonomi dan pengalaman prakerin terhadap minat berwirausaha sebesar $21,6 \%$, sedangkan sisanya sebesar $78,4 \%$ dipengaruhi oleh faktor - faktor lain diluar variabel dalam penelitian ini.
\end{abstract}

Kata Kunci : Literasi Ekonomi, Pengalaman Prakerin, Minat Berwirausaha. 


\section{PENDAHULUAN}

Salah satu masalah klasik yang dihadapi oleh negara berkembang adalah tingginya tingkat pertumbuhan penduduk dan banyaknya pengangguran. Banyaknya pengangguran berdampak langsung maupun tidak langsung terhadap peningkatan masalah sosial, kemiskinan dan kriminalitas. Menurut Rahayu (2017, hal.1), salah satu fenomena yang muncul di dunia pendidikan yaitu semakin tinggi pendidikan seseorang, maka kemungkinan dia menjadi pengangguran pun semakin tinggi. Hal seperti ini tidak hanya terjadi pada lulusan pendidikan saja tetapi pada sebagian besar masyarakat negara Indonesia. Mayoritas masyarakat Indonesia masih beranggapan bahwa yang menjadi karyawan dilatar belakangi pandangan negatif mengenai wirausahawan. "Diantaranya karena penghasilan yang tidak stabil, sifat agresif, persaingan keras dan ketidakamanan finansial. Berbeda dengan pekerjaan sebagai karyawan yang memiliki penghasilan tetap dan tidak memiliki resiko tinggi sehingga ada rasa aman" (Alma, 2010, hal.2).

Keadaan ketenagakerjaan (BPS, 2017) mengungkapkan, pada tahun 2017 telah terjadi kenaikan jumlah pengangguran di Indonesia sebesar 10.000 orang menjadi 7,04 juta orang pada Agustus 2017 dari Agustus 2016 sebesar 7,03 juta orang. Semakin bertambahnya jumlah pengangguran menjadikan Indonesia saat ini semakin memburuk. Kenyataan ini akan semakin memburuk jika tidak segera diatasi. Menurut Susanti (2017, hal.2), masalah pengangguran dapat diatasi dengan cara berwirausaha dan dengan menjadi pengusaha adalah alternatif untuk mengurangi jumlah pengangguran. Seseorang yang akan menjadikan dirinya sebagai pengusaha atau wirausaha haruslah menumbuhkan minat dalam dirinya untuk merintis usahanya mulai dari awal. Minat mempunyai peranan penting untuk memulai pekerjaan. Salah satu diantaranya adalah fenomena 7 dari 15 peserta didik sudah ada yang memiliki usaha, seperti online shop maupun menjual makanan yang dititipkan di kantin sekolah.

Menurut Santoso (2016, hal.19), mengungkapkan "minat berwirausaha adalah gejala psikis untuk memusatkan perhatian dan berbuat sesuatu terhadap wirausaha itu dengan perasaan senang karena membawa manfaat bagi dirinya". Minat menurut Slameto (2010, hal.180), adalah suatu rasa lebih suka dan rasa ketertarikan pada suatu hal atau aktivitas, tanpa ada yang menyuruh. Minat pada dasarnya adalah penerimaan akan suatu hubungan antara diri sendiri dengan suatu di luar diri. Minat tidak dapat dibawa sejak lahir, melainkan diperoleh dikemudian. Semakin kuat atau dekat hubungan tersebut, semakin besar minat. Menurut Puspita (2016, hal.228) menguraikan bahwa minat berwirausaha adalah keinginan, ketertarikan, serta kesediaan individu untuk bekerja keras dalam memenuhi kebutuhan hidupnya tanpa takut dengan resiko yang akan terjadi. Minat peserta didik dalam berwirausaha tidak timbul begitu saja tanpa adanya faktor-faktor yang mendukung". Ada tiga faktor itern yang mempengaruhi minat seseorang dalam berwirausaha yaitu motivasi, pengetahuan dan kepribadian dalam hal ini adalah keyakinan diri atau self eficacy. Dengan adanya faktor interen tersebut maka dapat memaksimalkan keinginan dan minat peserta didik dalam usaha. Berdasarkan uraian diatas dapa disimpulkan bahwa minat berwirausaha adalah keinginan, ketertariakan, dan kesediaan individu untuk bekerja keras untuk memenuhi kebutuhan hidupnya, biasanya diwujudkan dengan menciptakan suatu usaha atau bisnis baru yang berbeda dari yang lain dan berjiwa berani dalam menanggung resiko dalam proses mengembangkan usahanya.

Pendidikan sebagai suatu aspek yang menyumbangkan sumber daya manusia yang dimaksudkan untuk meningkatkan penge- 
tahuan dan kemampuan seseorang dalam berbagai kegiatan, juga diharapkan mampu membuka cara berfikir ekonomis dalam arti mampu mengembangkan potensi yang ada untuk memperoleh hasil semaksimal mungkin. Sejalan dengan hal tersebut maka pendidikan penting dalam memberikan literasi ekonomi kepada anak. Sedangkan literasi ekonomi perlu ditanamkan dan ditumbuhkan sejak dini sebab kemampuan literasi ekonomi tidak timbul dengan sendirinya tetapi sangat dipengaruhi oleh orang lain, termasuk keteladanan orang tua.

Menutur Thohir, dkk (2016) bahwa literasi bukan hanya saja menyangkut keahlian berfikir dan membaca melainkan menyngkut proses pembelajaran (learning) dan keahlian hidup (life skill) yang akan digunakan manusia, komunitas ataupun suatu bangsa untuk bertahan dan secara berkelanjutan mengalami perubahan. Namun pada kenyataannya tidak semua peserta didik mempunyai semangat dan pemahaman yang sama akan pentingnya literasi ekonomi, hal ini dibuktikan dengan beberapa peserta didik yang kurang antusias ketika berlangsungnya pelajaran ekonomi. Sehingga pemahaman pelajaran ekonomi masih belum sesuai dengan yang diharapkan. Literasi itu bukan hanya kemampuan membaca dan menulis saja, berhitung juga dapat disebut dengan literasi. Kebanyakan orang di Indonesia menganggap literasi sebagai persoalan psikologi, yang melibatkan kemampuan mental dalam membaca dan menulis. Mathews (dalam Supriyanto, 2016) menyatakan bahwa literasi ekonomi sebagai kemampuan individu untuk mengenali dan menggunakan konsep-konsep ekonomi dan cara berpikir ekonomi untuk memperbaiki dan mendapatkan kesejahteraan. Semakin tinggi literasi di suatu negara, maka semakin bagus budaya di negara tersebut. Namun pada kenyataannya tidak semua peserta didik mempunyai semangat dan pemahaman yang sama akan pentingnya literasi ekonomi, hal ini dibuktikan dengan beberapa peserta didik yang kurang antusias ketika berlangsungnya pelajaran ekonomi. Sehingga pemahaman pelajaran ekonomi masih belum sesuai dengan yang diharapkan. Dengan demikian, dalam bahasa sederhana literasi ekonomi adalah pengetahuan dan pemahaman konsep dasar ekonomi, prinsip-prinsip, dan aspek pengetahuan ekonomi praktis yang diperoleh dikelas.

Pada era globalisasi yang serba kompetitif di berbagai bidang kehidupan ini tampaknya pendidikan kejuruan menjadi sangat penting, mengingat tuntutan sumber daya manusia di pasaran tenaga kerja semakin tinggi. Pelaksanaan pendidikan pada Sekolah Menengah Kejuruan (SMK) adalah suatu proses pembelajaran dan bimbingan di sekolah dan ditambah proses praktik kerja di Dunia Usaha atau Dunia Industri yang sesungguhnya. SMK menghasilkan lulusan yang memiliki kompetensi pada bidang keahliannya, dan diharapkan mampu mengembangkan diri secara profesional sehingga dapat bekerja di lingkungan industri maupun bekerja secara mandiri (wirausaha), untuk mendukung tercapainya tujuan SMK melakukan Praktik Kerja Industri atau Prakerin.

Praktik Kerja Indusrti merupakan realisasi dari Pendidikan Sistem Ganda (PSG), yaitu suatu kegiatan pendidikan dan latihan kerja dengan mengembangkan kemampuan, kehlian dan profesi di tempat kerja sesuai dengan bidang keahliannya. Pengalaman prakerin secara tidak langsung akan memberikan pengetahuan dan pengalaman dalam bekerja. Pengalaman yang diperoleh pada saat melakukan praktik kerja industri secara tidak langsung akan mempercepat transisi siswa dari sekolah ke dunia kerja. Menurut Fadlilah, dkk (2016, hal. 6) seseorang dapat dikatakan berpengalaman apabila telah memiliki tingkat penguasaan 
pengetahuan dan keterampilan yang memadai dan sesuai dengan bidang keahlian yang diminatinya. Secara garis besar, pengalaman terbagi menjadi 2 yaitu: (1) pengalaman langsung yang diperoleh karena partisipasi langsung atau berbuat, (2) pengalaman pengganti yang diperoleh melalui observasi langsung, melalui gambar, melalui kata-kata, dan melalui simbol-simbol.

Menurut Hamalik dalam Sa'diyah (2016, hal.14), menyatakan bahwa praktik kerja lapangan atau praktik kerja industri atau yang dibeberapa sekolah disebut $O n$ the $J o b$ Training (OJT) merupakan model penelitian yang bertujuan untuk memberikan kecakapan yang diperlukan dalam pekerjaan tertentu seuai tuntutan kemampuan bagi pekerjanya tersebut. Kegiatan praktik kerja industri erat kaitannya dengan Pendidikan Sistem Ganda (PSG) yang dilaksanakan oleh SMK. Pengertian pendidikan sistem ganda menurut Kepmendiknas RI nomor 323/U/1997 tentang penyelenggaraan sistem ganda pada Sekolah Menengah Kejuruan, PSG adalah suatu bentuk penyelenggaraan pendidikan keahlian profesional yang memadukan secara sistematik dan sinkron program pendidikan di sekolah dan program penguasaan keahlian yang diperoleh melalui bekerja di dunia industri atau dunia kerja. Berdasarkan teori diatas maka dapat disimpulkan bahwa pengalaman praktik kerja industri merupakan ketrampilan dan pengetahuan yang diperoleh siswa pada saat mengikuti praktik kerja industri pada jangka waktu tertentu sehingga menjadi pribadi yang profesional, memiliki kemampuan dan pengetahuan, mempunyai motovasi dan kesiapan yang tinggi untuk menghadapi dunia kerja.

Praktik atau melakukan penelitian dilapangan merupakan kegiatan yang harus ditempuh oleh siswa dalam bentuk praktek kerja industri yang pada awal pelaksanaan PSG. Setelah mendapatkan pengalaman praktik kerja industri, maka perserta didik dapat menambah pengetahuan, memantapkan hasil belajar, membentuk sikap, menghayati dan mengenali lingkungan kerja. Serta peserta didik mampu menambah kemampuan dan keterampilan sesuai dengan bidangnya. Sehingga peserta didik dapat mengenal lebih dalam tentang dunia usaha atau dunia industri dan pada saat akan terjun dalam dunia usaha yang nyata maka peserta didik mampu beradaptasi dengan mudah dan cepat mengenai pekerjaan yang diperolehnya sesuai dengan bidangnya. Berdasarkan teori diatas maka dapat disimpulkan bahwa pengalaman praktik kerja industri merupakan ketrampilan dan pengetahuan yang diperoleh siswa pada saat mengikuti praktik kerja industri pada jangka waktu tertentu sehingga menjadi pribadi yang profesional, memiliki kemampuan dan pengetahuan, mempunyai motovasi dan kesiapan yang tinggi untuk menghadapi dunia kerja.

Sehingga dapat disimpulkan bahwa lierasi ekonomi dan pengalaman prakerin yang dimiliki oleh pesera didik akan menentukan minat berwirausaha. Dengan adanya pemahaman yang baik entang literasi ekonomi dan juga kemampuan peserta didik setelah mendapat pengalaman, maka peserta didik tersebut akan menumbuhkan minat dalam berwirausaha dalam kehidupannya.

Sesuai dengan latar belakang di atas, maka peneliti ingin menggali lebih mendalam seberapa besarkah masalah literasi ekonomi dan pengalaman prakerin ini mempengaruhi minat berwirausaha. Oleh karena itu, peneliti mengadakan penelitian dengan judul "Pengaruh Literasti Ekonomi dan Pengalaman Prakerin terhadap Mina Berwirausaha Peserta Didik Kelas XI Kompetensi Keahlian Administrasi Perkantoran (APK) SMK Negeri 1 Pogalan Tahun Pelajaran 2017/2018”.

\section{METODE PENELITIAN}

Penelitian ini merupakan jenis penelitian kuantitatif. Dalam penelitian ini 
menggunakan penelitian korelasional jenis sebab akibat atau biasa disebut kausal. Menurut Sugiyono (2012, hal.62) mengemukakan bahwa hubungan kausal adalah hubungan yang bersifat sebab akibat, jadi disini ada variabel independen (variabel yang mempengaruhi) dan variabel dependen (variabel dipengaruhi).

Menurut Arikunto (2013, hal.173) "populasi adalah keseluruhan subjek penelitian. Dalam penelitian ini, populasi yang digunakan adalah pesrta didik kelas XI Kompetensi Keahlian Administrasi Perkantoran (APK) yang berjumlah 73 terbagi dalam 2 kelas yaitu $\mathrm{APK}_{1}$ dan $\mathrm{APK}_{2}$. Teknik pengumpulan data dalam penelitian ini menggunakan angket (kuesioner). Untuk mengumpulkan data variabel Literasi Ekonomi $\left(X_{\nu}\right)$, Pengalaman Prakerin $\left(X_{2}\right)$, dan Minat Berwirausaha (Y) menggunakan angket (kuesioner) dengan skala likert. Menurut Sugiyono (2011, hal.93), "skala likert digunakan untuk mengukur sikap, pendapat dan presepsi seseorang atau sekelompok orang tentang fenomena sosial". Sebelum angket digunakan dalam penelitian dilakukan uji validitas dan uji reliabilitas. Uji validitas menggunakan rumus Product Moment, sedangkan uji reliabilitas menggunakan Cronbach's Alpha.

Untuk mengetahui valid tidaknya item angket menggunakan program SPSS 23.00 for windows, dengan ketentuan valid apabila nilai alpha kurang dari $(<) 0,05$. Analisis data yang digunakan adalah uji hipotesis yang meliputi uji t dan uji F, regresi linier berganda, serta koefisien determinasi, untuk memudahkan analisis data maka peneliti menggunakan bantuan program SPSS 23.00 for windows.

\section{HASIL DAN PEMBAHASAN \\ Uji Prasyarat}

\section{Uji Normalitas}

Uji normalitas menggunakan analisis statistic Kolmogrov-Smirnov Test dengan bantuan SPSS 23.00 for windows menunjukkan angka signifikansi 0.200 . Angka tersebut lebih besar dari 0,05 sehingga dapat disimpulkan bahwa data residual telah berdistribusi normal.

2. Uji Linearitas

\begin{tabular}{cccc}
\hline Variabel & $\begin{array}{c}\text { Linearit } \\
\mathbf{y}\end{array}$ & $\begin{array}{c}\text { Deviation } \\
\text { from } \\
\text { Linearity }\end{array}$ & $\begin{array}{c}\text { Kete- } \\
\text { rangan }\end{array}$ \\
\hline $\begin{array}{c}\mathrm{X}_{1} \\
\text { terhadap Y }\end{array}$ & 0.002 & 0.101 & Linear \\
$\begin{array}{c}\mathrm{X}_{2} \text { terhadap } \\
\mathrm{Y}\end{array}$ & 0.000 & 0.261 & Linear \\
\hline
\end{tabular}

Sumber data : Data Hasil Olahan Peneliti, 2018

3. Uji Multikolinearitas

\begin{tabular}{lccc}
\hline \multicolumn{1}{c}{ Variabel } & Tolerance & VIF & Keterangan \\
\hline $\begin{array}{l}\text { Literasi } \\
\text { Ekonomi }\left(\mathrm{X}_{1}\right)\end{array}$ & 0.968 & 1.033 & $\begin{array}{c}\text { Tidak } \\
\text { terjadi } \\
\text { multikoli- } \\
\text { nearitas }\end{array}$ \\
$\begin{array}{l}\text { Minat } \\
\text { Berwirausaha }\end{array}$ & 0.968 & 1.033 & $\begin{array}{c}\text { Tidak } \\
\text { terjadi } \\
\text { multikoli- } \\
\text { nearitas }\end{array}$ \\
\hline
\end{tabular}

Sumber data : Data Hasil Olahan Peneliti, 2018

\section{Uji Heterokedastisitas}

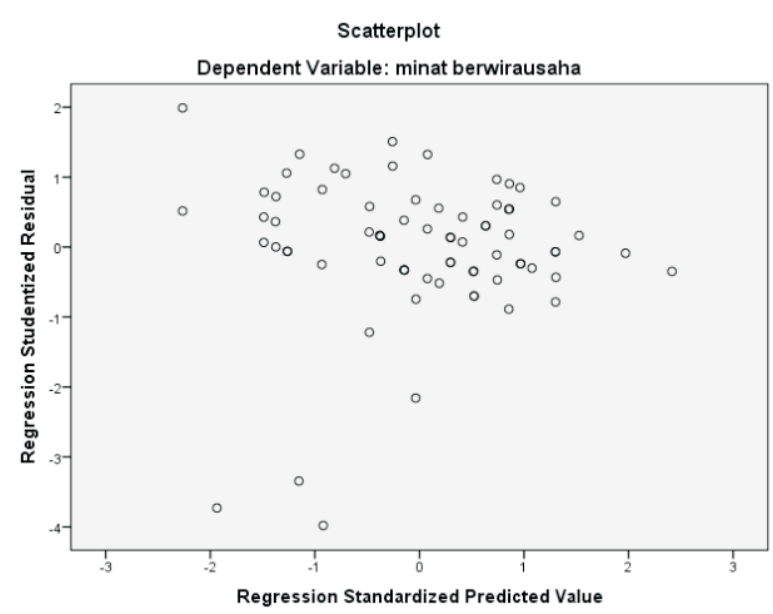

Sumber data : Data Hasil Olahan Peneliti, 2018 


\section{PEMBAHASAN}

\section{Intepretasi Hasil Penelitian}

Berdasarkan hasil analisis data dengan Statistical Package for Social Science (SPSS) for Windows version 23,0 menunjukkan bahwa persamaan regresi linier berganda $\mathrm{Y}=33,494+0,348 \mathrm{X}_{1}+$ $0,175 \mathrm{X}_{2}$ bahwa jika variabel independen (literasi ekonomi dan pengalaman prakerin) sebesar 0 (nol), maka nilai variabel dependen (minat berwirausaha) sebesar 33,494. Koefisien regresi $X_{1}$ (literasi ekonomi) sebesar 0,348 menyatakan bahwa setiap penambahan satu satuan variabel $\mathrm{X}_{1}$ (literasi ekonomi), maka hal ini akan berpengaruh pada peningkatan variabel Y (minat berwirausaha) sebesar 0,348 dan sebaliknya apabila terjadi penurunan satu satuan variabel $\mathrm{X}_{1}$ (literasi ekonomi), maka variabel Y (minat berwirausaha) mengalami penurunan sebesar 0,348 dengan ketentuan variabel lain adalah tetap/tidak berubah. Koefisien regresi dari $\mathrm{X}_{2}$ (pengalaman prakerin) sebesar 0,175 menyatakan bahwa setiap penambahan satu satuan variabel $\mathrm{X}_{2}$ (pengalaman prakerin), maka hal ini akan berpengaruh pada peningkatan variabel Y (minat berwirausaha) sebesar 0,175 dan sebaliknya apabila terjadi penurunan satu satuan variabel $X_{2}$ (pengalaman prakerin), maka variabel $\mathrm{Y}$ (minat berwirausaha) mengalami penurunan sebesar 0,175 dengan ketentuan variabel lain adalah tetap atau tidak berubah.

\section{Perbandingan Hasil Penelitian dengan Teori}

a. Variabel literasi ekonomi terhadap minat berwirausaha

Dalam penelitian ini peneliti memperoleh hasil bahwa ada pengaruh literasi ekonomi dan pengalaman prakerin terhadap minat berwirausaha. Hasil penelitian ini mendukung teori Supriyanto (2016), "literasi ekonomi yang diperoleh dari lingkungan pendidikan, dalam hal ini bisa diperoleh dari mata pelajaran ilmu pengetahuan sosialekonomi dan kegiatan yang bermuatan kewirausahaan, memiliki hubungan yang sangat erat dan sangat berpengaruh terhadap munculnya minat berwirausaha pada peserta didik". Selain itu juga mendukung teori yang dikemukakan oleh Gregov dkk (2014), "pelajaran ekonomi di sekolah bisnis dapat memunculkan literasi ekonomi dan akivitas wirausaha. Bila pembelajaran ekonomi berjalan dengan baik, maka akan menghasilkan literasi ekonomi yang baik pula. Tentunya hal ini akan terjadi jika guru ekonomi yang mengajar juga berkualitas baik".

Literasi ekonomi merupakan merupakan mata pelajaran yang diberikan oleh guru mata pelajaran ekonomi atau ilmu pengetahuan sosial - ekonomi yang digunakan untuk menentukan taraf penguasaan kompetensi atau tingkat keberhasilan dari pencapaian pembelajaran mengenai teori-teori umum tentang ilmu ekonomi yang bermuatan kewirausahaan. Sehingga dapat disimpulkan bahwa litserasi ekonomi berpengaruh terhadap minat berwirausaha.

b. Variabel pengalaman prakerin terhadap minat berwirausaha

Dalam penelitian ini peneliti memperoleh hasil bahwa ada pengaruh pengalaman prakerin terhadap minat berwirausaha. Hasil penelitian ini mendukung teori tautul Mahfud (2012) "untuk membentuk siswa menjadi seseorang wirausaha, tidak cukup dengaan bakat yang dimiliki saja, namun siswa juga harus memiliki pengetahuan usaha yang akan ditekuni, serta siswa memerlukan pembelajaran secara nyata dengan melibatkan secara langsung dalam kegiatan berwirausaha". Selain itu, juga mendukung teori yang dinyatakan oleh 
Muhamad Nur (2015), “faktor lain yang mempengaruhi minat berwirausaha siswa adalah faktor ketertarikan, faktor dari keluarga, faktor dari guru, faktor dorongan dari teman dan lain-lain”. Dan juga mendukung teori yang dinyatakan oleh Puspita (2014), "minat peserta didik dalam berwirausaha tidak timbul begitu saja tanpa adanya faktor-faktor yang mendukung". Ada tiga faktor itern yang mempengaruhi minat seseorang dalam berwirausaha yaitu motivasi, pengetahuan dan kepribadian dalam hal ini adalah keyakinan diri atau self eficacy. dengan adanya faktor interen tersebut maka dapat memaksimalkan keinginan dan minat peserta didik dalam usaha.

Pengalaman prakerin merupakan merupakan sutau pengetahuan dan keterampilan yang diketahui dan dikuasai oleh peserta didik setelah melakukan praktik pada dunia usaha/dunia industri, untuk membekali peserta didik agar dapat menumbuhkan sikap dan keterampilan sesuai dengan bidang keahliannya dan cara berfikir masing-masing guna dapat membuka suatu usaha atau bisnis baru Sehingga dapat disimpulkan bahwa pengalaman prakerin berpengaruh terhadap minat berwirausaha.

\section{Perbandingan hasil penelitian yang dilakukan dengan penelitian yang relevan}

a. Variabel literasi ekonomi terhadap minat berwirausaha

Dalam penelitian ini peneliti memperoleh hasil bahwa ada pengaruh positif dan signifikan literasi ekonomi terhadap minat berwirausaha pesera didik kelas XI Kompetensi Keahlian administrasi perkantoran (APK) SMK Negeri 1 Pogalan tahun pelajaran 2017/ 2018. Hasil penelitian ini mendukung penelitian terdahulu yang dilakukan oleh
Muhammad Thohir, dkk. yang berjudul "Pengaruh Status Sosial Ekonomi Orang Tua, Lierasi Ekonomi Dan Percaya Diri Terhadap Minat Wirausaha Siswa SMP NE G E R I D I K E C A M A T A N TENGGILIS MEJOYO SURABAYA. Variabel dalam penelitian ini adalah Status Sosial Ekonomi Orang Tua $\left(\mathrm{X}_{1}\right)$, Lierasi Ekonomi $\left(\mathrm{X}_{2}\right)$ dan Percaya Diri $\left(\mathrm{X}_{3}\right)$ sebagai variabel bebas dan minat wirausaha sebagai variabel terikat (Y).

Teknik analisis dalam penelitian ini menggunakan Regresi linier berganda guna mengetahui pengaruh variabel bebas secara bersama-sama terhadap variabel terikat. Koefisien regresi pada variabel literasi ekonomi yang dihasilkan adalah positif yaitu sebesar 0,147 hal ini menunjukkan bahwa jika literasi ekonomi naik satu satuan maka minat wirausaha akan naik sebesar 0,147 satuan dengan asumsi variabel sosial ekonomi orang tua dan percaya diri adalah konstan. Hasil uji F menjelaskan bahwa status sosial ekonomi keluarga, literasi ekonomi, dan percaya diri secara simultan atau bersamasama berpengaruh signifikan pada minat berwirausaha, hal ini terlihat dari nilai $\mathrm{F}_{\text {hitung }}$ yang dihasilkan sebesar 53,240 lebih besar dari $\mathrm{F}$ tabel sebesar 2,65 dengan nilai signifikansi $\mathrm{p}=0,000$ lebih kecil dari $5 \%$. Nilai t-hitung pada variabel persepsi siswa $\left(\mathrm{X}_{2}\right)$ sebesar 7.231 dengan tingkat signifikan kurang dari 5\% yaitu 0.000 . Artinya persepsi siswa $\left(\mathrm{X}_{2}\right)$ secara parsial berpengaruh signifikan pada hasil belajar $\operatorname{siswa}(Y)$.

Hipotesis ada pengaruh signifikan literasi ekonomi terhadap minat wirausaha siswa terjawab dari hasil nilai t-hitung sebesar 2,388 dengan tingkat signifikan kurang dari 5\% yaitu 0,018 Hal ini berarti bahwa literasi ekonomi secara parsial berpengaruh signifikan terhadap minat wirausaha siswa. 
Berdasarkan penelitian terdahulu dan penelitian yang dilakukan peneliti dapat disimpulkan terdapat pengaruh positif literasi ekonomi terhadap minat berwirausaha.

b. Variabel pengalaman prakerin terhadap minat berwirausaha

Dalam penelitian ini peneliti memperoleh hasil bahwa ada pengaruh positif dan signifikan pengalaman prakerin terhadap minat berwirausaha pesera didik kelas XI Kompetensi Keahlian administrasi perkantoran (APK) SMK Negeri 1 Pogalan tahun pelajaran 2017/2018. Hasil penelitian ini mendukung penelitian terdahulu yang dilakukan oleh Eva Susanti (2017) yang berjudul "Pengaruh Pengalaman Praktik Kerja Industri (Prakerin) Terhadap Minat Berwirausaha Siswa Kelas XI Kopetentsi Keahlian Akuntansi (AK) SMK Negeri 1 Pogalan Tahun Pelajaran 2017/2018.

Populasi dalam penelitian ini adalah siswa kelas XI Kompetensi Keahlian akuntansi SMK Negeri 1 Pogalan yang berjumlah 105 siswa. Sampel pada penelitian berjumlah 51 siswa diambil dari $50 \%$ populasi. Teknik pengambilan sampling dilakukan dengan cara propotional random sampling. Metode pengumpulan data menggunakan angket. Metode ini digunakan untuk memperoleh data pengalaman prakerin $(\mathrm{X})$ dan minat berwirausaha (Y). Dari hasil analisis terbukti bahwa nilai signifikansi sebesar 0,000 maka, 0,000 $<0,005$ berarti $\mathrm{H}_{\mathrm{O}}$ diolak dan Ha diterima. Dengan demikian dapat disimpulkan bahwa "ada pengaruh yang signifikan antara pengalaman prakerin terhadap minat berwirausaha siswa kelas XI Kompetensi Keahlian akuntansi (AK) di SMK Negeri 1 Pogalan tahun pelajaran 2016/2017. Serta mendukung juga pada penelitian yang sebelumnya oleh Oktafiani Putri Astuti dan Dr. Mutiara Nugraheni (2016) yang berjudul "Pengaruh Pengalaman Praktik Kerja Indusri Terhadap Minat Berwirausaha Siswa Jasa Boga SMKN 1 Sewon Ahun Pelajaran 2016". Hasil penelitian menunjukkan bahwa:

1. Pengalaman praktik kerja industri dengan kategori baik 57\%, kategori cukup $43 \%$ dan kategori rendah $0 \%$.

2. Minat berwirausaha siswa dengan kategori baik 38\%, kategori cukup $62 \%$, dan kategori rendah $0 \%$.

3. Terdapat pengaruh yang signifikan antara pengalaman praktik kerja industri terhadap minat berwirausaha sebesar 20,5\% dan sebesar 79,5\% dipengaruhi oleh faktor diluar penelitian ini.

Berdasarkan kedua penelitian terdahulu dan penelitian yang dilakukan peneliti dapat disimpulkan terdapat pengaruh positif pengalaman prakrin terhadap minat berwirausaha.

\section{PENUTUP}

\section{Simpulan}

1. Secara parsial terdapat pengaruh yang signifikan antara literasi ekonomi $\left(\mathrm{X}_{1}\right)$ terhadap minat berwirausaha $(\mathrm{Y})$ peserta didik kelas XI Kompetensi Keahlian Administrasi Perkantoran (APK) SMK Negeri 1 Pogalan tahun pelajaran 2017/2018. Hal ini terbukti bahwa nilai $\mathrm{t}_{\text {hitung }}(2,725)>\mathrm{t}_{\text {tabel }}(1,994)$ dengan signifikasi $0,008<0,05$. Dengan demikian $\mathrm{H}_{\mathrm{o}}$ ditolak dan $\mathrm{H}_{\mathrm{a}}$ diterima sehingga dapat dinyatakan bahwa ada pengaruh yang signifikan literasi ekonomi $\left(\mathrm{X}_{1}\right)$ terhadap minat berwirausaha $(\mathrm{Y})$.

2. Secara parsial terdapat pengaruh yang signifikan pengalaman prakerin $\left(\mathrm{X}_{2}\right)$ terhadap minat berwirausaha (Y) peserta didik kelas XI Kompetensi Keahlian Administrasi Perkantoran (APK) SMK Negeri 1 Pogalan tahun pelajaran 
2017/2018. Hal ini terbukti bahwa nilai $\mathrm{t}_{\text {hitung }}(3,250)>\mathrm{t}_{\text {tabel }}(1,994)$ dengan signifikasi $0,002<0,05$. Dengan demikian $\mathrm{H}_{\mathrm{o}}$ ditolak dan $\mathrm{H}_{\mathrm{a}}$ diterima sehingga dapat dinyatakan bahwa ada pengaruh yang signifikan hasil belajar mata kuliah praktik kewirausahaan $\left(\mathrm{X}_{2}\right)$ terhadap minat berwirausaha (Y).

3. Secara simultan terdapat pengaruh signifikan antara literasi ekonomi $\left(\mathrm{X}_{1}\right)$ dan pengalaman prakerin $\left(\mathrm{X}_{2}\right)$ terhadap minat berwirausaha (Y) peserta didik kelas XI Kompetensi Keahlian Administrasi Perkantoran (APK) SMK Negeri 1 Pogalan tahun pelajaran 2017/2018. Hal ini terbukti bahwa $F_{\text {hitung }}(10,940)>F_{\text {tabel }}$ 3,13 dan tingkat signifikan $0,000<0,05$. Dengan demikian $\mathrm{H}_{\mathrm{o}}$ ditolak dan $\mathrm{H}_{\mathrm{a}}$ diterima sehingga dapat dinyatakan bahwa ada pengaruh signifikan antara literasi ekonomi $\left(\mathrm{X}_{1}\right)$ dan pengalaman prakerin $\left(\mathrm{X}_{2}\right)$ terhadap minat berwirausaha (Y) peserta didik kelas XI Kompetensi Keahlian Administrasi Perkantoran (APK) SMK Negeri 1 Pogalan tahun pelajaran 2017/2018.

\section{Saran}

Berdasarkan kesimpulan diatas maka penulis memberikan saran kepada peserta didik hendaknya lebih percaya diri dalam pemahaman literasi ekonomi supaya mendapatkan nilai dan pemahaman yang memuaskan. Serta pihak sekolah hendaknya membantu peserta didik untuk memotivasi agar mendapatkan pemahaman yang baik serta dapat menumbuhkan minat berwirausaha

\section{DAFTAR PUSTAKA}

Alma, Buchari. (2010). Kewirausahaan Untuk Mahasiswa dan Umum. Bandung: Alfabeta.
Arikunto, Suharsimi. (2013). Prosedur Penelitian Suatu Pendekatan Praktik. Jakarta: PT Rineka Cipta.

Astuti, Putri Oktafiani, dkk. (2016). Pengaruh Pengalaman Praktik Kerja Industri Terhadap Minat Berwirausaha Siswa Jasa Boga SMKN 1 Sewon.

Badan pusat statistik. (2017). https:// www.bps.go.id/pressrelease/2017/11/0 6/1377/agustus -tingkatpengangguran-terbuka-tpt-sebesar-550-persen. Diakses pada 15 April 2018.

Fadlilah, Farida, dkk. 2015/2016. Pengaruh Lingkungan Keluarga Dan Pengalaman Praktik Kerja Indutri Terhadap Minat Berwirausaha Siswa SMK.

Puspitaningsih, F. (2014). Pengaruh Efikasi Diri Dan Pengetahuan Kewirausahaan Terhadap Minat Berwirausaha Melalui Motivasi, Vol. 2. No. 2, Tahun 2014. Jurnal Ekonomi Pendidikan Dan Kewirausahaan.

Rahayu, W. S. (2017). Pengaruh Hasil Belajar Mata Kuliah Kewirausahaan Terhadap Minat Berwirausaha Mahasiswa Program Studi Pendidikan Ekonomi Semester VI SKIP PGRI Tulungagung Tahun Akademik 2016/2017.

Sa'diyah, Kalimatus Masfi. (2016). Pengaruh Pengalaman Praktek Kerja Industri dan Hasil Belajar terhadap Kesiapan Kerja Siswa Kelas XII Program Keahlian AK SMKN 1 Rejotangan.

Supriyanto. (2016). Pengaruh Kegiatan Ekstrakulikuler, Percaya Diri Dan Literasi Ekonomi Terhadap Minat Berwirausaha Siswa SMPN Di Surabaya, Vol. 4. No 2, Tahun 2016. 
Sugiyono. (2011). Metode Penelitian Kuantitatif, Kualitatif dan $R \& D$. Bandung: Alfabeta.

Sugiyono. (2012). Metode Penelitian Kuantitatif, Kualitatif dan Kombinasi (Mixed Methods). (Sutopo, Ed) (ke 2). Bandung: Alfabeta,cv

Susanti, Eva. (2016). Pengaruh Pengalaman Praktik Kerja Industri (Prakerin) Terhadap Minat Berwirausaha Siswa
Kelas XI Kompetensi Keahlian Akuntansi (AK) SMKN 1 Pogalan Tahun Pelajaran 2015/2016

Thohir, Muhammad, dkk. (2016). Pengaruh Status Sosial Ekonomi Orang Tua, Literasi Ekonomi Dan Percaya Diri Terhadap Minat Wirausaha Siswa SMP Negeri Tenggilis Mejoyo Surabaya, Vol. 4. No. 2, Tahun 2016 